\title{
TV/Series
}

Hors séries 1 | 2016

Lost: (re)garder l'île

\section{Lost's Ending: the Junction of Time and Timeless Discourse}

\section{Vladimir Lifschutz}

Translator. Brian Stacy

\section{Q OpenEdition \\ Journals}

\section{Electronic version}

URL: http://journals.openedition.org/tvseries/4968

DOI: 10.4000/tvseries.4968

ISSN: 2266-0909

\section{Publisher}

GRIC - Groupe de recherche Identités et Cultures

\section{Electronic reference}

Vladimir Lifschutz, «Lost's Ending: the Junction of Time and Timeless Discourse », TV/Series [Online], Hors séries 1 | 2016, Online since 01 December 2020, connection on 05 December 2020. URL : http:// journals.openedition.org/tvseries/4968; DOI : https://doi.org/10.4000/tvseries.4968

This text was automatically generated on 5 December 2020

\section{cc)}

$T V /$ Series est mis à disposition selon les termes de la licence Creative Commons Attribution - Pas d'Utilisation Commerciale - Pas de Modification 4.0 International. 


\title{
Lost's Ending: the Junction of Time and Timeless Discourse
}

\author{
Vladimir Lifschutz
}

Translation : Brian Stacy

1 The mere mention of Lost's ending usually suffices to grab listeners' attention. We began watching Lost ourselves at age sixteen. We can vividly recall the first episodes aired on TF1 in summer 2005. We thought "Oh boy! They'd better know where they're going with this. If it were up to us, we'd have had the series end with the first season, so that we could find out if the survivors from Oceanic flight 815 would make it off the island. We longed for an answer to Charlie's question at the end of the TV series' pilot: "Guys, where are we?". As our patience was tested, we began to watch Lost with greater detachment. We began to settle into the idea that the show could run for several more years - until the decision to wrap up the series in its sixth season gave our expectations a deadline. From that point on, we could revert back to being patiently impatient knowing that our wait would pay off. As we researched and prepared this work, memories of all these feelings flooded back into our minds. Each of us has our own stories with Lost, having formed what one might call a "way of watching" the series. One's personal history is necessarily embedded in a time period. Whether you followed Lost while it was being aired (by following the American web broadcast, or on French television) or whether you enjoyed the show on DVD, download or video on demand, no matter when you watched or tuned in, we all experienced its story in our own way. This is what we could call "spectatorial time", that is, the memory of the time shared with the fiction and what we got out of it. The series' greatest specificity seems to me to be its highly peculiar structuring of time. A time of remembrance, of anticipation, of alternation, a time for constructing identity and affect, a time for sharing and discussion.

2 From a more pragmatic standpoint, each season of Lost revolves around two different time trajectories. We'll come back to this point later on. By focusing on this temporal specificity, we see that Lost's ending is intended to create an impossible junction between two of the narrative's temporalities and form a discourse aimed at pushing the 
work forward into a timeless future. Remembering the show beyond its initial broadcast, turning the end into the pivotal moment when the series takes the opportunity to live on in our collective memory. It is through a kind of philosophy of endings that we venture to understand the role of "narrative" closure within as lengthy and unusual a series as Lost. The present article doesn't weigh in on debates about the show's ending; nor will we attempt to pass judgment on the latter's merits, but rather we will focus on its workings in relation to time and viewers.

What counts as Lost's ending? The last season? The last episode? For our purposes, we refer to the final minutes of the last episode as Lost's ending. This choice is prescribed by our approach to endings, which borrows its theoretical framework from Paul Ricoeur and Frank Kermode. We agree on the point that every conclusion comes about through a rupture, a point of no return, which Ricœur defines as the passage from narrative immanence to an imminent ending of the narrative. This powerful idea drawn from the works of Frank Kermode ${ }^{1}$ suggests that every narrative is based on the idea of an immanent end continually postponed by the presence of a "crisis", but that a concomitant turning point at the end of the crisis makes it possible to proceed to the narrative's imminent ending. Of interest to us here are this turning point and the modalities following from it: "Crisis does not indicate the absence of every end but the conversion of the imminent end into an immanent end ${ }^{2}$." According to the theory, imminence causes us feel the end is near. Lost's turning point seems to be when Jack meets his father. This final encounter is the culmination of a lengthy quest. Jack had in fact always been searching for a father figure, long before Christian Shephard's death. Once on the island, the "visions" of his father lead him to set out in search of his father's body. The anamnesis (or loss of amnesia) is one of the last season's pivotal narratives, as it is about retrieving the pragmatic and emotional memory of the events on the island in the temporality of the flash-sideways. In a recurring mirror effect, all the characters awaken to memories of theirs except Jack, who continues to suffer from amnesia until the show's final minutes. He is the first figure to wake up on the island and the last to do so at the end. Within the logic of the sixth season, the awakening of all the characters sets in motion the story's ending. Jack's anamnesis therefore logically what triggers Lost's ending. During this concluding father/son reunion, Jack overcomes his amnesia and awakens to memories of his life on the island. Our point of no return is therefore Jack's awakening, which constitutes a reflexive effect tipping off viewers to the imminence of Lost's ending. From then on, viewers are fully aware that the end has gotten underway.

\section{"Deformulating" the "formula"}

4 Following Ricoeur's logic, we believe that breaking points in TV series can cause what we call a "deformulation" of the "formula". We've borrowed the term "formula" from Jean-Pierre Esquenazi. The formula refers to the "strict framework of a TV series," ${ }^{3}$ that is, its structural, aesthetic, aural and temporal framework that gives it, week after week, a distinctive identity. In Lost for example, the two timelines coexist, taking up all of the series' episodes. One of the lines remains constant throughout the seasons, the present time on the island. The other timeline is defined in relation to the first. In the first three seasons, the second timeline is featured in flashbacks. Thereafter, they can be flashforwards and in the last season, flash-sideways. The "deformulation" implies a 
genuine break with what's previously been established, that the framework is transcended to accommodate the upsetting of set codes.

5 One of the first overt examples of deformulation involves the musical score used in the show's final moments. Lost's ending is accompanied by a musical composition by Michael Giacchino entitled "Moving On" running 7 minutes to 55 seconds, the lengthiest piece composed for the series. The track combines several of Lost's several recurring musical themes (including "Life \& Death", "There's no place like home", "Oceanic 815 ", to name a few), making for a score that echoes the series' soundscape. Said music gradually pervades the last scene, welling up into an increasingly intense musical wave that fuels on-screen footage, particularly in terms of rhythm. By doing something never done before, Giacchino effects a musical revolution through an aural compendium of the fiction's recurring themes halfway between homage and novelty.

In an article entitled "Fins de séries", authors Laura Odello and Peter Szendy metaphorically refer to the end as "shutdowns":

One could put it this way: the series, as a succession of narrative promises that follow on from one another in a certain cumulative escalation, is also drawn into a spiral of debt. What's at stake is precisely the taking out of a kind of accumulating narratological bankloan. As a result, series' endings are almost always remarkable moments when the serial economy on the verge of default engages in a game of speculation: how can we close out all the accounts, how will we repay all the loans taken out from viewers, despite the fact that the logic of narrative capitalization aims rather to heighten expectations, to constantly raise their ceiling, to issue ever greater promises ${ }^{4}$ ?

7 The metaphor is noteworthy as it highlights the difficulty of reconciling an ending with viewers' expectations. The idea of liquidation or shutdown appears relevant to us since it brings about to a form of derailment of the established system. The idea of "deformulation" seems to fit this conception. The narrative train charging full speed ahead is not slowed down but hastened towards derailment. Just how did Lost's writers orchestrate this moment of derailment/shutdown/deformulation?

\section{There is no 'now' here}

8 The final dialogue between Jack and his father plays a twofold role. First of all, shortly beforehand, touching the coffin triggers Jack's anamnesis, the memory of his fictional past. In terms of technique, Jack's realization is dramatized via an editing device consisting of a fast-paced montage of recycled fictional images and footage calibrated to sharpen colors, producing a faintly dreamlike effect. These sequences reveal themselves to be flash-sideways, temporality outside of time, between life and death, time of anamnesis, time created by the protagonists to retrieve and remember. This timeline thus serves to "prepare the spectators at the end of the series, to help them through a process of grief and retrospection: to remember highlights through flashbacks, to look back on the road travelled, to bear in mind what we've experienced over the past six years.". In this process of "deformulation", the dialog between Jack and Christian marks a point of no return since it goes beyond the bounds of mortality. Christian Shephard's words function as a twofold discourse emphasizing this point. "There is no now, here" could be translated meta-filmatically as "All this is fiction, it's not real". "Everybody dies sometimes, kiddo" could be construed as "Everything has an end, even Lost". "This is a place that you all made together so you can find one 
another," sounds like an explanation of what the series is, a place of fiction created with the audience's assistance in order to share stories. "The most important part of your life was the time that you spent with these people, that's why all of you are here [...] you needed all of them and they needed you" rings out as an explanation of the bond between fiction and viewers: as writers, the adventure of Lost is the hallmark experience of our lives. We needed you and you needed us. The theoretical materialization of this most special bond is conveyed through the symbolism-laden "To remember and let go" which accompanies viewers in their grieving process, helping them think back on the fiction and achieve closure. This is summed up by the expression "Moving on" which rounds out this process of rupture, as if the writers were confiding: "We're not abandoning you, we are moving on to new projects, hopefully with your continued support. "The series not only culminates with Jack's anamnesis and the meeting with his father, it clearly states this, taking viewers by the hand just like the guiding Christian character does. We all have our own way of looking at the world and Christian appeals to everybody's personal experience; the writers use Jack's father's words to summarize the Lost experience for themselves, for the characters, and for the viewers-a novel threefold discourse embodying the essence of "deformulation".

9 The question of time is important. Jack needs to know where he is, but Christian can't fulfil that need, hence "there is no now here. " The time of flash-sideways is out of time. Unlike the flashbacks scattered throughout the show's six seasons or the flashforwards starting at the end of the third season, the flash-sideways don't fit into the broader pragmatic chronology of Lost. Whereas the other timelines occupy a precise space, the alternative time is meant to be a time of imminence outside of time. One can nevertheless pinpoint them; take two of Lost's sequences as examples. The first is Juliet's death in "LAX Part 1" (S6E01). Just before dying, she utters strange words whose meaning is made clear in Lost's finale, "End Part II" (S6E18). Juliet wasn't rambling; she had somehow torn the veil of time, allowing her to perceive and merge two temporalities. Sawyer and Juliet's anamnesis provides some perspective on this junction with the dialog echoing Juliet's words at the time of her death. The articulation of this new relationship to time is based on an understanding requiring viewers to bring their memories back up to date. It is in fact impossible to understand this new temporal relationship without bearing in mind the two episodes. The other sequence that breaks down time boundaries is the last sequence in the final episode in which a near-death Jack senses the other time.

\section{An extraordinary junction of time}

For the first time, in the same episode, in the same scene, the two timelines structuring the whole of Lost come together. These two trajectories are subject to variations throughout the series, but they never meet simultaneously. Flashbacks generally function in the manner of what Gérard Genette calls external analepses ${ }^{6}$ which he defines as outside of the primary narrative - in Lost, the events that occurred before the plane crash usher in the series. As such, there can be no simultaneous junction with the primary narrative. As for flashforwards, they function similarly to Genette's prolepses: one can distinguish between scenes eventually merged with the primary narrative (complementary prolepses) and those that repeat a future narrative segment (repetitive prolepses) ${ }^{7}$. When a flashforward upsets the passage of time in the third 
season finale, the story is split up: we follow both one story taking place in the present and another unfolding in the future. The primary narrative subsequently seeks to link up with this new narrative segment, which it succeeds in doing in the fourth season finale. However, the junction does not take place at the same time. While the first narrative completes the flashforwards, the latter continues to advance. So there are temporal junctions in Lost, but ones based on a kind of compounding structure. The junctions fails to impugn the two timelines since they do not meet simultaneously. Since the two timelines are ever-present forces, it seems impossible to conflate the two timelines into one at the same time. This remains the case into the last season, which proposes a time presented primarily as an alternative event trajectory within the show.

11 However, the last sequence achieves the impossible junction of two timelines continually collided and juxtaposed throughout the show, pursuing a level of completeness that seems impossible until this last scene. Through an alternating series of montage effects based on spliced movement, the two timelines begin to coexist. Jack becomes aware of his twofold presence, at once on the island and in the church.

Figures 1 and 2: Lost's closing montage; the meeting of two temporalities, the island in Lost's present and the flash-sideways.

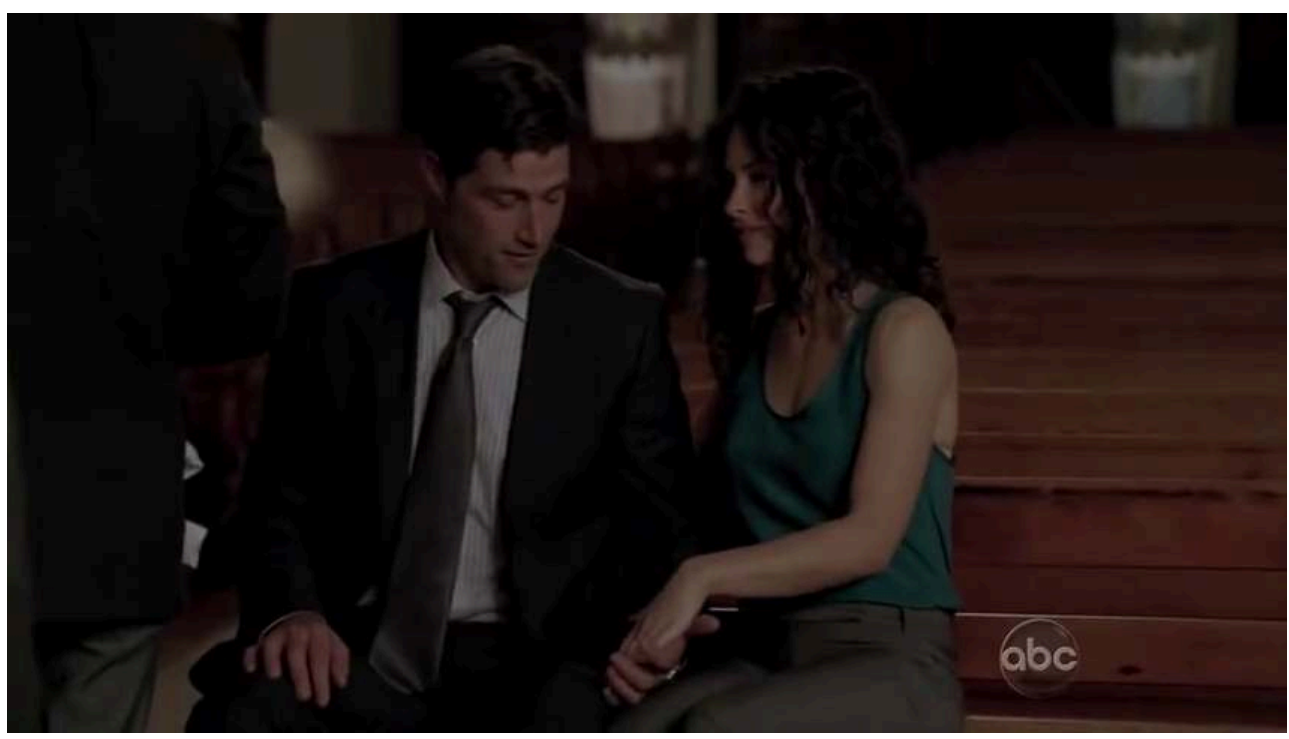




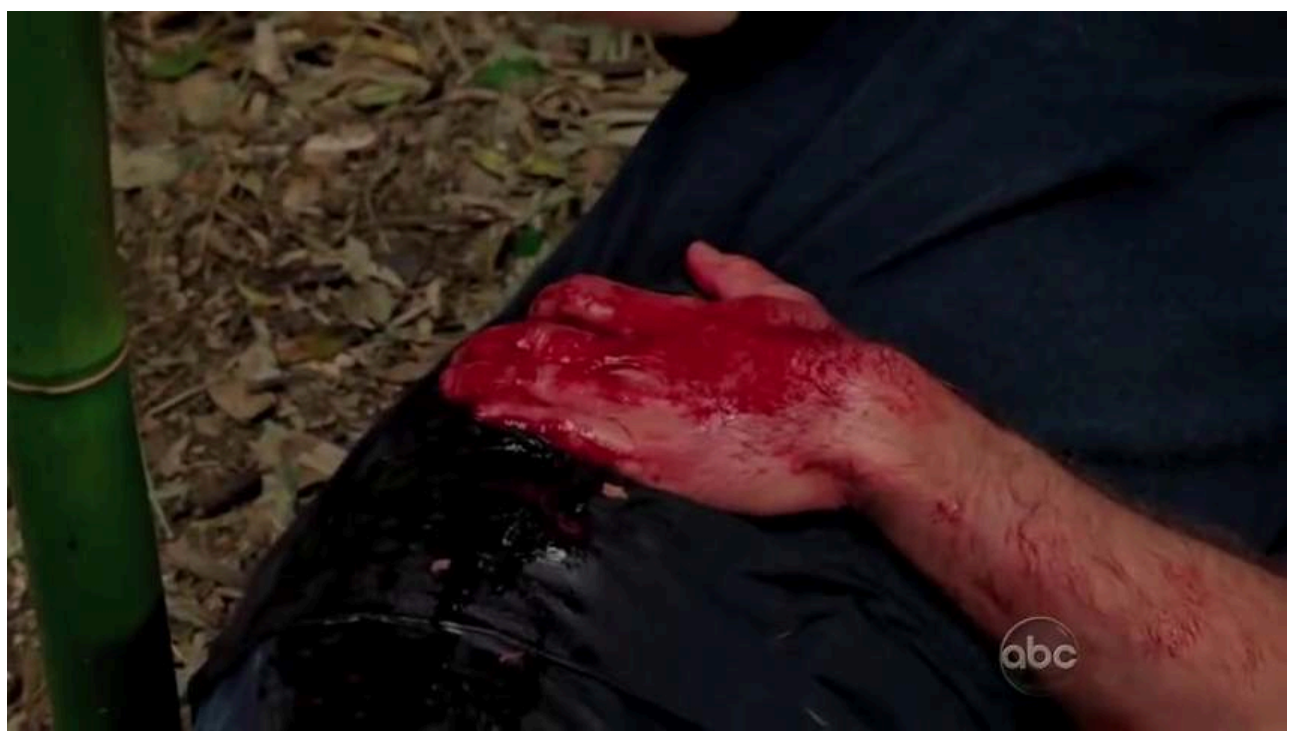

12 Thanks to the montage, characters' gestures become time's binding agents. Jack collapses in the forest as he sits in church; Kate's hand lain overtop Jack's mimics Jack applying pressure to his wound; the presence of the dog refers to the father figure ${ }^{8}$. While synchonized motions provide the montage with coherence, viewers' gaze effectively merges the timelines. The eye unscramble the two timelines, allowing Jack to experience the imminence of his end in the form of a recitation across two moments. of course, the closed eye, the bamboo forest and the presence of the dog refer back to the pilot episode in a reflexive form prompting us to re-examine the series. Furthermore, the junction of time creates a time horizon unbridgeable for a fiction built on two timelines. The timelines only appear to meet at the end of the show. As Jack slowly drifts away, the final appearance of the plane leaving the island metaphorically depicts Jack's departure towards death, the departure so yearned for throughout the series and a letting go of the distinctive universe that sustained a lasting crisis.

Figures 3 and 4: Jack watches the plane depart in the series' last moments

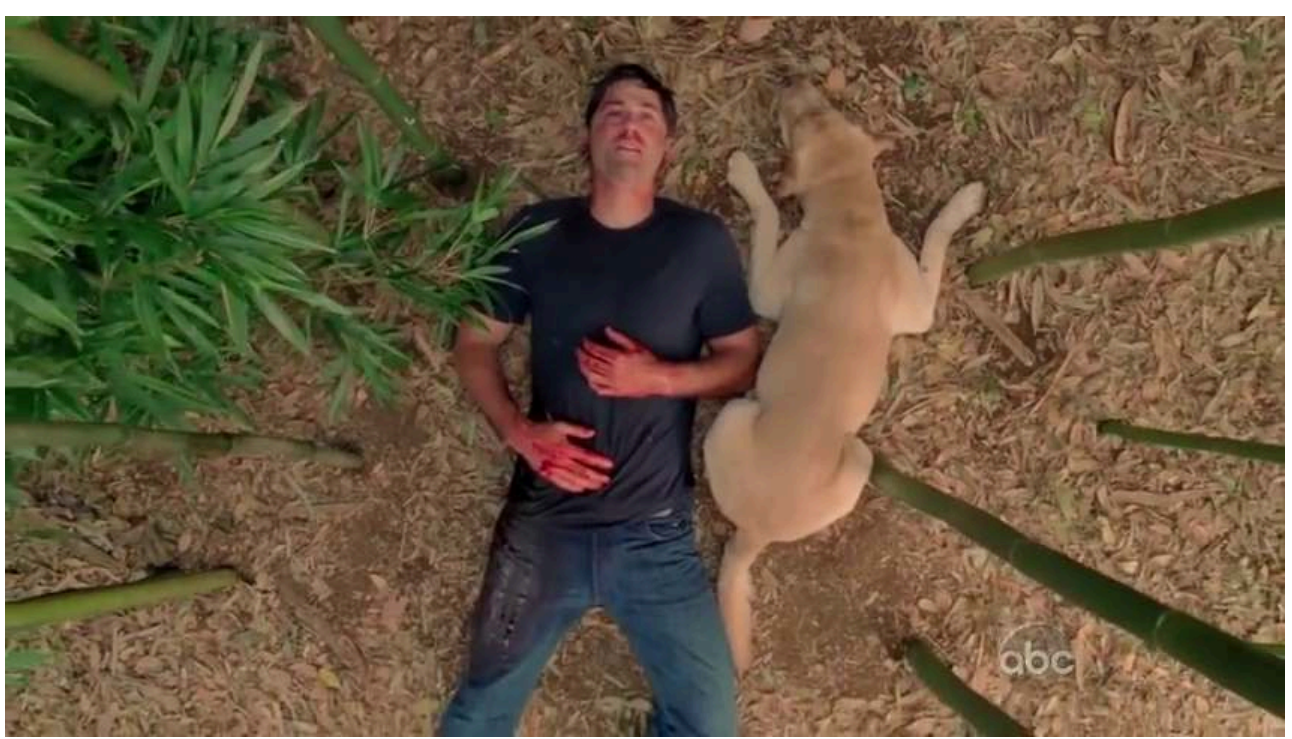




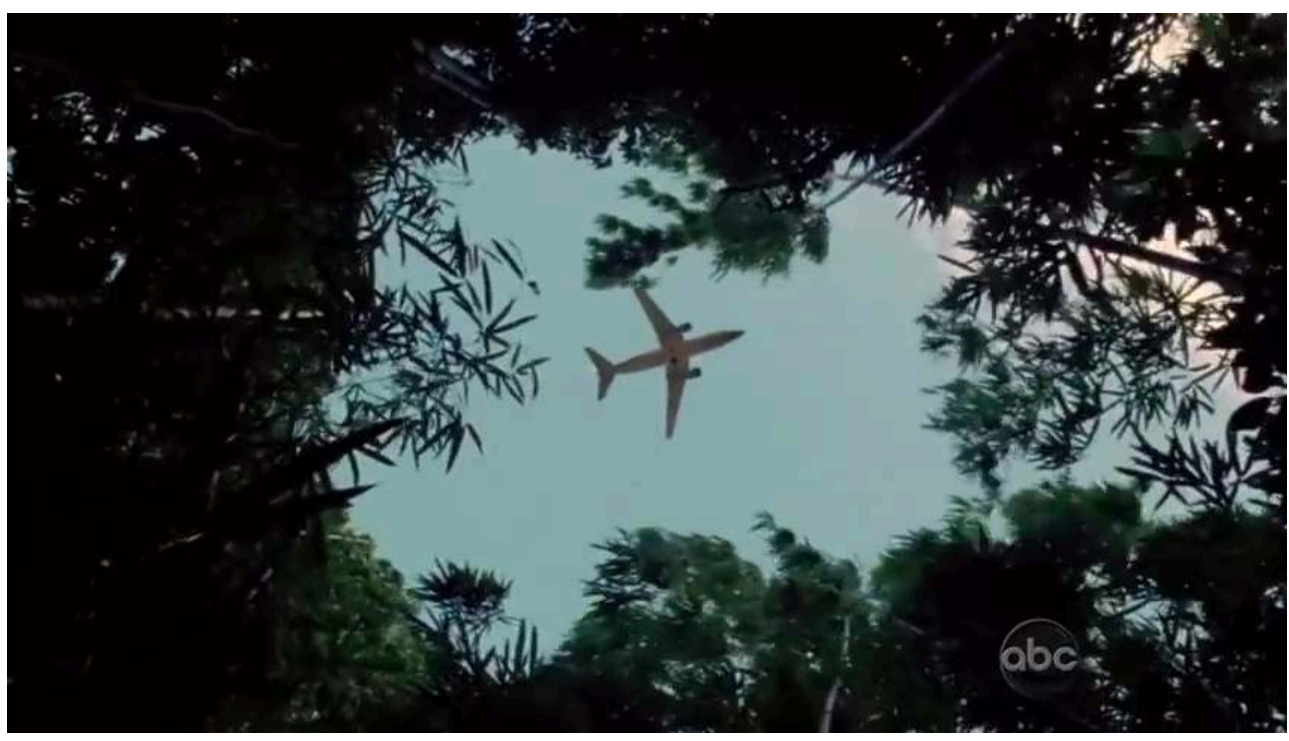

13 The staging revolves around Jack: the camera is pointed frontward as seen from the character's point of view, but before that, it turns about him, always slightly off-center from his gaze, then facing him squarely in the very last shot. The shutting eye no longer probes time, it scans the viewers, producing Lost's last new junction between the character's time with the viewers' time. The camera waits right up until the end of the sequence to turn towards Jack's gaze, as if the lens had just noticed something unique about it. Just like Pacôme Thiellement, we feel that "The specificity of Lost is to have shown us that to look is not only to undergo; to look is to see; and to see is to be ${ }^{9}$. The visual effects of Lost are not only to be seen, but also to be seen, to be seen, to be seen." Such a visual scheme suggests that we are no longer experiencing the action of a fiction in the way Jack is. The gaze forms the affirmation of our identity.

Jack's death is symbolized by a fade to white, recalling the way death is displayed visually in Six Feet Under (Alan Ball, HBO, 2001-2005). This is not the first time that fades to white are employed in Lost. In fact, they're used in three instances. The first is during the implosion of the Swan station at the end of the second season, the consequences of which aren't revealed until the beginning of the third season. The second fade to white upends the time continuum as Ben sets the island in motion, both in space and time. The third is the implosion of the nuclear warhead by Juliet at the tail end of the fifth season. Each of these fades denotes a change in the island's state (damage to the magnetic field, displacement of the island in space and time, the apparent - creation of another timeline). However, in this final sequence, the fade to white no longer serves the same purpose. It stands rather for the junction of the two temporalities. When the fade to white erases the flash-sideways, Jack's eye closes. This white light affirms the imminence of Jack's death, which comes peacefully. Unlike other uses of fades to white, this one isn't a harbinger of disturbance, but of a peaceful temporal reunification. Jack sees beyond his own temporality and this sight makes sense to him. In the scene's closing frames, the rear tracking shot in which the camera pulls away from Jack gives way to a reverse angle showing some survivors flying away by plane. While a similar tracking shot in the pilot introduced us to Jack's presence on the island, this last camera sweep announces his exit. Jack's initial quest is met with a kind of fulfilment, since departure from the island forms a core part of Lost's narratives. 


\section{Disturbance of the sensory-motor schema} motor schema, i.e. our ability to move and perceive our environment. The mise en scène shifts from a movement image to a time image, to quote the words of Gilles Deleuze. The movement image is based on a causal relationship, a situation-perceptionaction relationship (example: I am thirsty, I have a bottle in front of me, I pick up the bottle to drink). In the last scene, Jack's grave injury disrupts his sensor-motor schema. He can still feel but moves less and less. The image then attempts to depict purely optical and aural experiences reminiscent of Deleuze's time image. The staging thus shifts from an audiovisual scheme based on the movement image to a more ambiguous scheme, wherein we're no longer included in the movement image without yet being fully part of the time image. As Deleuze reminds us, the postulate of a single world crumbles when confronted with the time image. Nevertheless, this sequence is not a "pure" time-image inasmuch as video editing induces an indirect form of time perspective, but the time image/movement image boundary is indeed blurred.

The time image seems to presuppose an absence of editing by means of the sequence shot, but this is not necessarily so clear-cut because, as Deleuze states:

Editing remains in most cases the essential cinematographic act. However, it shifts in meaning: instead of arranging the movement images so as to produce an indirect image of time, it breaks down the relationships into a direct time-image so that all possible movements flow out of it ${ }^{10}$.

Lost's ending attempts to bring out the movements of time that permeate the show. Jack is limited only to a purely visual experience which intensifies as his body shuts down. Lost calls on us to think about the relationship to time through mise en scène. By blurring the boundaries separating movement image and time image, the series proves its ability to reappropriate cinematic properties and integrate them into its own discourse and processes.

\section{Timeless discourse}

The junction of time serves to deformulate the narrative since such a junction doesn't occur anywhere earlier on in the series. It is also worth noting the silent inset of the title "LOST" after the final sequence - previously, this title was accompanied by a rumbling sound. The sequence is introduced with a soothing mood suggesting a dissipation of the tension having pervaded the show there prior. The series episode completely breaks with the series' usual formula.

As we mentioned at the beginning of the article, we all watch Lost in our own way, but these differences may mask a shared core. We value these characters and we have a special relationship with them, what Jean-Pierre Esquenazi calls mediacy, media legacy, the "acquired knowledge about television ${ }^{11 "}$. We could broaden the meaning of this term to include the knowledge we've gained through the viewing of a fiction set in this medium. Some of us may remember Hurley's flashbacks better than Sawyer's or vice versa, but we all share in a kind of collective memory. 

scriptwriters, the network heads and the viewers. In addition, with the rise of new consumer markets, producers must think about series' viability after broadcasting (sale of DVDs, Blu-ray, etc.). They must successfully transition between what we call the initial airing stage and the multi-media reappropriation phase. A show's ending plays a pivotal role here, a turning point that may or may not inspire others to reappropriate the work. The deformulation opted for by Lost's writers appears to anticipate and facilitate such multi-media reappropriations. In the last sequence, the writers give Lost viewers an eminent role. Christian Shephard's discourse theorizes about the relationships forged with fiction based on writers' expressions of acknowledgement to their audience. In Lost, the end sequence relies on the subsequent reactivating of the series' emotional content. The reunion is made that much stronger by the fact that certain characters (Boone, Libby or even Locke) had disappeared from the show for several seasons. The sequence, borne forward by embraces and knowing glances, convokes our memory of the entire series. Without words, the reunion aims to produce a catharsis in the Aristotelian sense, a kind of purging of feelings for both characters and viewers. The glances, the hugs, the handshakes translate the flows of affection between the characters and encourage viewers to re-examine their spectatorial memory. As Shawn Ryan reminds us: "For me, the hallmark of a series that will go down in the annals of television is an ending that makes you want to re-examine the beginning ${ }^{12}$." Lost is a perfect example of this, as the series encourages recollection while asserting a timeless discourse.

Indeed, the flash-sideways fall outside any traditional temporality. Perhaps they are an ever-present time, since Desmond can accede to them during his lifetime, but their ultimate goal is to connect the experiences had on the island - a temporal space to prepare for the post-mortem experience requiring one to first remember life. As we have seen, Christian's speech and the reunion in the church tend to reactivate viewers' fictional memory. When Jack meets Boone again, part of the first season is invoked.

The most obvious mark arousing a desire to revisit the beginning is, of course, Jack's death, which perfectly echoes his awakening in the pilot episode. In this way, the fiction flows through Jack's gaze as he opens and closes the series, as if, without him, the show would no longer be possible. In hindsight, the inverted parallelism effect between the end and the beginning suggests a kind of time loop. This final reference to the beginnings of the series marks the authors' desire to make their series into a selfreflexive fiction or a "reflexive palimpsest ${ }^{13}$ ". The series rewrites its own story, since the flash-sideways construct an alternative narrative. 
Figures 5 and 6: Jack opening his eyes in the pilot and closing them in the final episode.
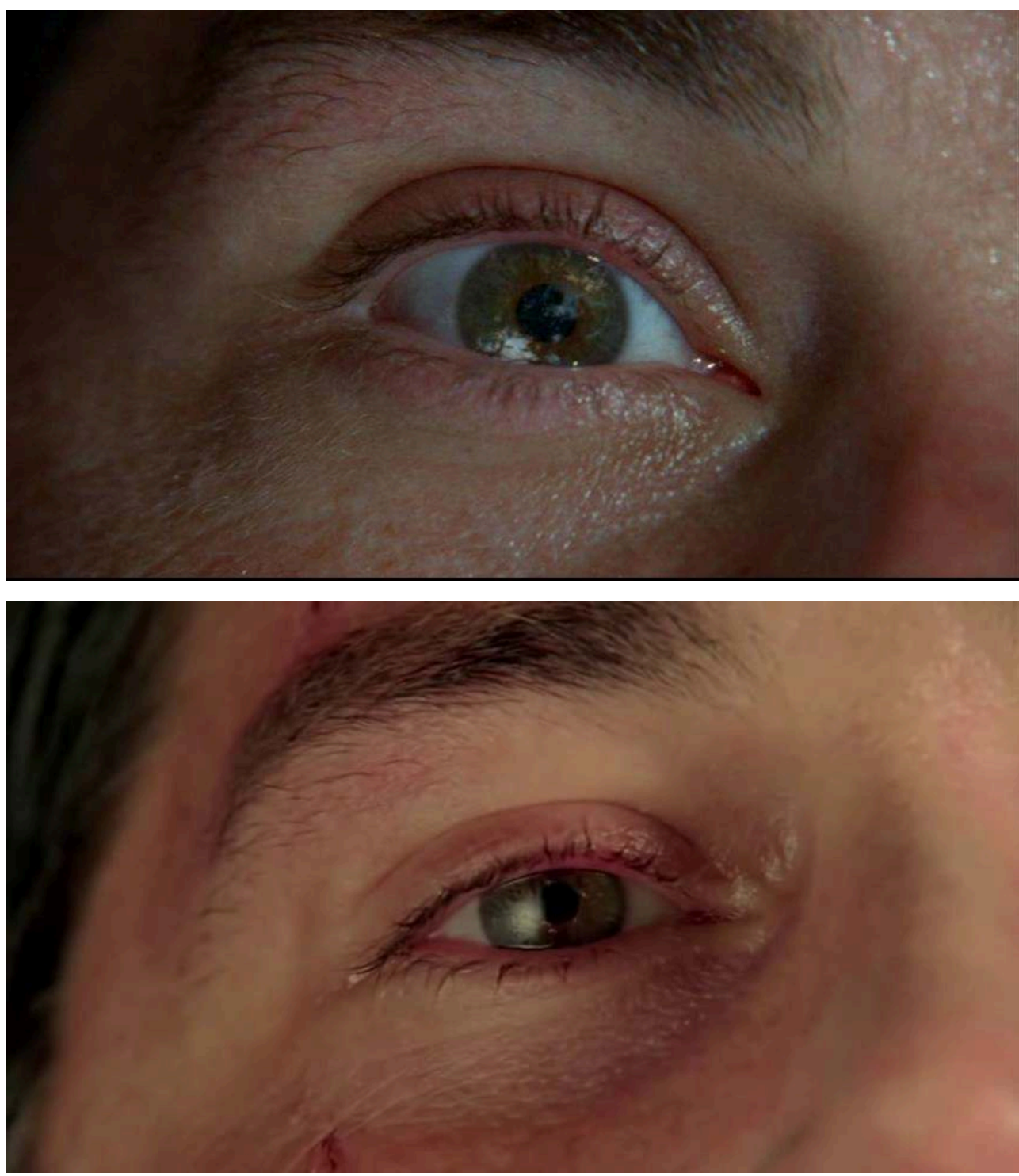

The writers' discourse therefore appears to follow a timeless form. The end reactivates the many emotional forces that shaped the series. As Christian suggests, what is real is what has been shared with these people. This triangle of emotion includes viewers, the characters and the writers. The moments shared between all the characters, but especially between the viewers and the characters, transform the experience into an emotional journey. The platform that is Lost is a collective undertaking in the sense that the writers, with the collaboration of the viewers, were able to fashion a fictional shared world. The timelessness of Lost's discourse is precisely the space-time of flashsideways, a purely fictional time that eludes all approaches to thinking about time in order to make serial fiction prevail in what it most explicitly produces - the triumph of human relations.

24 The ending marked by Jack's death offers an opening to the continuity of the universe: the island continues to exist with a new protector. Lost seems to take an almost cyclical, gaze-driven approach to the serial narrative. The writers privilege the end of an experience over the end of a universe. The Lost experience is therefore rooted in a 
timelessness made possible by the way viewers watch it and by the idea that emotions conveyed live on the end of the fiction.

By hinging the end around a new time dimension and a new junction, Lost asserts the specificity of its temporal discourse. Aware that viewers place the Lost experience in a specific mode of viewing inducing a time-based appropriation, the authors sum up this idea by giving it substance and shape and by proposing to make flash-sideways a temporality of the "viewer" in which each person can adopt his or her own manner of viewing. The central character of Christian embodies the figure of the writer taking the character/viewer by the hand to lead them through the experience of the passage from immanence to the imminence at the story's end. In this way, Lost creates the conditions for a reinvestment in the show, since the end impels us to re-examine the whole series. As Locke states in the episode "Orientation" (S2E03) in one of the phrases that contributed to the series' success: "We're going to have to watch that again." The final junction of time is also that of two temporalities - that of the show and that of the viewers who repeated over several years the same action as Jack, opening and closing his gaze with each passing episode. The writers attempt to reconcile two incompatible temporalities, fiction and reality. However, just as Jack cannot escape his physical state as a fictional character, the viewers cannot physically step into the story. The veil makes the opposite temporality visible but prevents one from crossing the thresh-hold; only emotion seems to bridge the gap between fiction and reality. To reprise the idea of "shutdown", Lost owes a debt to its viewers. The time spent watching the series must be paid for. As Sarah Hatchuel reminds us, "While viewers have devoted much of their time, their lives, their energy towards understanding, searching, decoding, the series has given them back their own lives (perhaps changed, even transcended) in return. ${ }^{14}$ " The experience of the show emphasizes the role of emotion and the two-way circulation effected by the latter. Jack finally constructs himself through the relationships he has with the other characters. Jack the Cartesian moves through the show, eventually becoming a man of faith and replacing Jacob. He shapes his identity during the series, helped along by emotions shared with the other characters. In the last minutes of Lost, Jack's peace of mind appears to coincide with a dual temporal perception enabling him to put into perspective the path he's traveled. Jack can rest in peace: he's understood that the value of his experience lies in the emotions that shaped him.

Damon Lindelof and Carlton Cuse propose an ending buoyed by a "deformulation" breaking with the temporal, aural and aesthetic structure (the photography in the church scene features ultra-soft lighting and calibration employed nowhere else in Lost). "Nobody does it alone, Jack", yet Jack collapses alone on the island, but his solitude is illusory insofar as he is surrounded by emotion. As Pacôme Thiellement's analyzes:

And, as a mirror of death, they must remember (their true nature), let go (of their passions) and set out themselves into another dimension. But it is also a mirror of life for viewers. And the viewer must move on (in his own life), let go (of the story) and remember, in turn, his divine nature. This life-in-death is our life as viewers. ${ }^{15}$.

Christian could have added "Death is not the end", as the end of the series doesn't point to him having died. The emotions of which it is crafted are carried on by the viewers, ensuring it a form of continuity in another world. We continue to discuss Lost; we keep telling our friends to watch the show, we re-experience the show. When we wanted Lost 
to be over with - even in its first season - we couldn't possibly have imagined to what extent the question of time would lend the show its trademark aura.

\section{BIBLIOGRAPHY}

DELEUZE Gilles, L'Image-temps, Paris, Les éditions de Minuit, 1985.

ESQUENAZI Jean-Pierre, Les séries télévisées : l'avenir du cinéma ?, Paris, Armand Colin, 2010.

GENETTE Gérard, Discours du récit, Paris, Éditions du Seuil, 1972.

HATCHUEL Sarah, Lost : Fiction Vitale, Paris, Presses universitaires de France, 2013.

KERMODE Frank, The Sense of an Ending, New York, Oxford University Press, 2000.

ODELLO Laura et SZENDY, "Fins de séries », Artpress2 : Séries télévisées formes, fabriques, critiques, février/mars/avril 2014, n³2, p. 36-41.

RICEEUR Paul, Temps et Récit 2. La configuration dans le récit de fiction, Paris, Le Seuil, 1984.

THIELLEMENT Pacôme, Les mêmes yeux que Lost, Clamecy, Éditions Léo Scheer, 2011.

\section{NOTES}

1. Frank Kermode, The Sense of an Ending, New York, Oxford University Press, 2000.

2. Paul Ricœur, Temps et Récit 2. La configuration dans le récit de fiction, Paris, Le Seuil, 1984, p. 49.

3. Jean-Pierre Esquenazi, Les séries télévisées : l'avenir du cinéma ?, Paris, Armand Colin, 2010, p. 26.

4. Laura Odello and Peter Szendy, "Fins de séries", Artpress 2 : séries télévisées formes, fabriques, critiques, February/March/April 2014, no. 32, p. 36-41.

5. Sarah Hatchuel, Lost : Fiction Vitale, Paris, Presses universitaires de France, 2013, p. 124.

6. Gérard Genette, Discours du récit, Paris, Éditions du Seuil, 1972, p. 39.

7. Ibid., p. 66.

8. We also note the kiss between Juliette and Sawyer, an overt reference to the kiss exchanged during Sawyer's death (S6E01).

9. Pacôme Thiellement, Les mêmes yeux que Lost, Clamecy, Éditions Léo Scheer, 2011, p. 53.

10. Gilles Deleuze, L'Image-temps, Paris, Les éditions de Minuit, 1985, p. 170.

11. Esquenazi, p. 5 :

12. Lost, saison 6, DVD, ABC Studio, 2010, bonus, documentary, "La création de la dernière saison".

13. Hatchuel, p. 116.

14. Hatchuel, p. 134.

15. Pacôme Thiellement, p. 113-14. 


\section{ABSTRACTS}

This text offers a questioning on the ending of Lost from a temporal and aesthetic angle. As it has been the source of many strong controversies, the conclusion of Lost gives us an opportunity to wonder about the way we watch the show. Through our deformulation theory, we shall analyze how fiction unravels before us while accomplishing the impossible junction of two antinomic temporal lines. The show sets up a strong connection with the TV viewer as it elaborates a final double-speech whose second listener is the TV viewer. Through a subtle and coherent final cut, the authors of Lost connect our experiences, the temporal lines, and the characters in a same goal: producing an emotional catharsis, whose scope tends to indefinitely engrave the fiction in the collective memory. Lost reminds us that the value of the ending also consists in having shared some affect with someone else, since Lost is a fiction about Lost characters who, during the last moments of the fiction, find themselves.

Ce texte propose de s'interroger sur la fin de Lost sous un angle temporel et esthétique. Source de nombreux débats intenses, la conclusion de Lost nous offre une occasion de nous interroger sur notre manière de regarder la série. En nous appuyant sur notre théorie de la déformulation, nous analyserons la manière dont la fiction se défait sous nos yeux tout en réalisant l'impossible jonction de deux lignes temporelles antinomiques. La série établit un lien fort avec le téléspectateur en élaborant un double discours final dont le second destinataire est le téléspectateur. Par un montage final subtil et cohérent, les auteurs de Lost lient nos expériences, les lignes temporelles, les personnages dans un même but, provoquer une catharsis émotionnelle, dont la portée, tend à inscrire la fiction dans la mémoire collective de manière indéfinie. Lost nous réapprend que la fin a de la valeur dans la mesure où nous avons partagé des affects avec autrui. Parce que Lost est une fiction sur des personnages perdus qui, dans les derniers instants de la fiction, se trouvent.

\section{INDEX}

Keywords: Lost, deformulation, time-image, movement-image, ending, conclusion, closure Mots-clés: Lost, déformulation, image-temps, image-mouvement, fin, conclusion, dénouement

\section{AUTHORS}

\section{VLADIMIR LIFSCHUTZ}

Vladimir Lifschutz completed his thesis in film studies at the University of Lyon 2 under the direction of Jean-Pierre Esquenazi and Martin Barnier. He works on the question of temporal patterns in TV series, on the question of how to end a TV show, and on the fictional universe and the aesthetic and narratological dimensions of fiction. He is also interested in narrative mutations and the history of stories.

Vladimir Lifschutz a achevé un doctorat en étude cinématographique à l'université Lumière Lyon 2 sous la direction de Jean-Pierre Esquenazi et Martin Barnier. Il travaille sur la question des configurations temporelles dans les séries télévisées, mais aussi sur les clôtures de série, les univers fictionnels et la dimension esthétique et narratologique des œuvres sérielles. Il s'intéresse plus largement aux mutations narratives et à l'histoire des récits. 